\title{
Christian Perspectives in Education
}

\author{
Send out your light and your truth! Let them guide me. Psalm 43:3
}

Volume 1

Issue 1 Fall 2007

Article 5

November 2007

\section{Enhancing Christian School Experiences for Pre-Service Teachers through Service-Learning Partnerships}

\author{
Karen L. Parker \\ Liberty University, kparker@liberty.edu \\ Beth E. Ackerman \\ Liberty University, mackerman@liberty.edu \\ Leonard W. Parker \\ Liberty University, Iwparker@liberty.edu
}

Follow this and additional works at: https://digitalcommons.liberty.edu/cpe

\footnotetext{
Recommended Citation Education, 1(1).

Available at: https://digitalcommons.liberty.edu/cpe/vol1/iss1/5

This Article is brought to you for free and open access by the School of Education at Scholars Crossing. It has been accepted for inclusion in Christian Perspectives in Education by an authorized editor of Scholars Crossing. For more information, please contact scholarlycommunications@liberty.edu.
}

Parker, Karen L.; Ackerman, Beth E.; and Parker, Leonard W. (2007) "Enhancing Christian School Experiences for Pre-Service Teachers through Service-Learning Partnerships," Christian Perspectives in

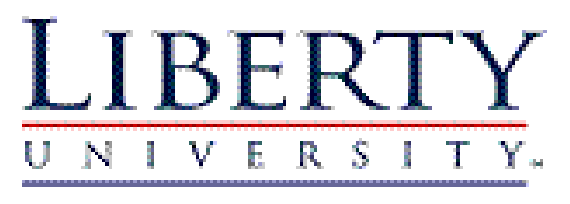


Enhancing Christian School Experiences for Pre-Service Teachers through Service-Learning Partnerships

\section{Cover Page Footnote}

Bernette Beckles, M.Ed. Liberty Christian Academy 
Multiple terms are used to describe the various field experiences and internships that are designed for students in higher education. Partnerships and professional development schools are two examples of service-learning that have emerged in the preparation of school personnel. There has also been increasing awareness of "service-learning" in teacher education within the past decade. The American Association of Colleges of Teacher Education (AACTE), one of the leading organizations in teacher education, has a National Service-Learning in Teacher Education Partnership (NSLTEP) project that was founded in 2001 (www.servicelearningpartnership.org). NSLTEP is designed to help develop institutional capacity and interinstitutional infrastructure to incorporate service-learning in teacher education programs. The aim of this partnership is to promote service-learning in teacher education programs so that these future teachers can also promote this to their young students. In the early 1990's, teacher education programs started including service-learning as part of their curriculum and their students' experiences for a variety of reasons.

Anderson (1998) cites the positive effects for teacher candidates in developing the professional attitudes and values needed for success in student teaching and in teaching. Servicelearning introduces a social-emotional component to the intellectual learning of course content, and teaching becomes more student-centered (Hickcox, 2002). "Engaged scholarship" is a term associated with service-learning to reflect the participatory aspect (Hodge, Lewis, Kramer \& Hughes, 2001) that links personal/interpersonal with academic/cognitive development and enhances student retention (Hubbert, 2002) as well as personal and professional growth (Valo, 1999). The value of action learning, as perceived by college students, should be tested by measures of their competence before and after the learning experience, in addition to assessing their competence in the field after graduation (Lizzio \& Wilson, 2004). 
The historical roots of higher education in America are grounded in a spiritual mission to prepare the clergy for a life of serving others. In contemporary religious institutions, servicelearning provides a concrete expression of a life of faith (Antoci \& Speck, 2002). Graham (2003) describes a service component in the description of the learning activities for redemptive teaching, "learning is connected with service to others as pervasively as possible" (p. 235).

An emphasis on the spiritual development of students is the distinguishing feature of Christian colleges and universities, which goes beyond the social-emotional aspects acknowledged by secular institutions of higher education. Certain attributes are common among Christian institutions that naturally foster the integration of service and learning (Schaffer, 2004). The primary attribute is the values-centered curriculum and co-curriculum at Christian colleges and universities. Their emphasis on teaching over research and smaller class sizes also facilitates service-learning.

Schaffer (2004) examined unpublished materials from 90 Christian colleges and universities and interviewed educators at seven of the institutions to identify the best practices of service-learning in a Christian academic setting. Five key elements of best practices emerged from the study: (a) institutional support, (b) mission, (c) definitions and guidelines, (d) academic validity, and (e) faith and learning tool.

Wilson and Johnson (2001) emphasized the character virtues of exemplary mentors. In addition to performing certain functions, mentors are also called upon to be a certain kind of person. Effective mentors should model integrity and a caring attitude in their relationships with others and in their professional practice. A service-learning partnership between two Christian institutions has the double benefit of Christian mentors in both settings, which includes the Christian university as well as the local Christian school. 
The National Society for Experiential Education defines service-learning as "any carefully monitored service experience in which a student has intentional learning goals and reflects actively on what he or she is learning throughout the experience" (Furco, 1996, p. 1). The service-learning partnership in this study meets this definition, as this is a course-embedded experience in which the tutors (teacher candidates) are completing reflections throughout their experience as well as a final survey that reflects on their knowledge of the field of education.

Sigmon (1994) takes this definition a step further by defining the various levels of service-learning. The effectiveness of service-learning can be seen in the typology in Figure 1. This typology can assist in "clarifying the distinctions between the various types of experiential education programs" (Furco, 1996, 2).

\begin{tabular}{|l|l|}
\hline \multicolumn{2}{|l|}{ Figure 1: A Service and Learning Typology (Sigmon, 1994) } \\
\hline Service-LEARNING & Learning goals primary; service outcomes secondary \\
\hline SERVICE-learning & Service outcomes primary; learning goals secondary \\
\hline Service-learning & Service and learning goals completely separate \\
\hline SERVICE-LEARNING & $\begin{array}{l}\text { Service and Learning goals of equal weight and each } \\
\text { enhances the other for all participants }\end{array}$ \\
\hline
\end{tabular}

In order to demonstrate the balanced focus for service-learning depicted in Figure 2, the service-learning project should actually contribute to solving a problem in the community (Harkavy \& Romer, 1999) and should also provide academic benefit for the college participants. Higher education faculty will typically "see the world through the lens of their discipline" and may not realize that the connection between course objectives and service is not apparent to the teacher candidates. Bringle and Hatcher (1997) recommend effective reflection to enable college participants to make the connection. Effective reflection is linked to the following components: 
learning objectives, guided, scheduled regularly, feedback provided, and clarified values. In addition to guided reflection, Hasseler (2002) recommends strength-based school settings and opportunities to learn about factors that affect school settings, such as societal structures and school contexts. Conceptualization, operationalization, ongoing assessment, and agency relationship are key factors to be considered by faculty members when designing a servicelearning course (McGowan, 2002).

Figure 2. Balanced focus for service-learning.

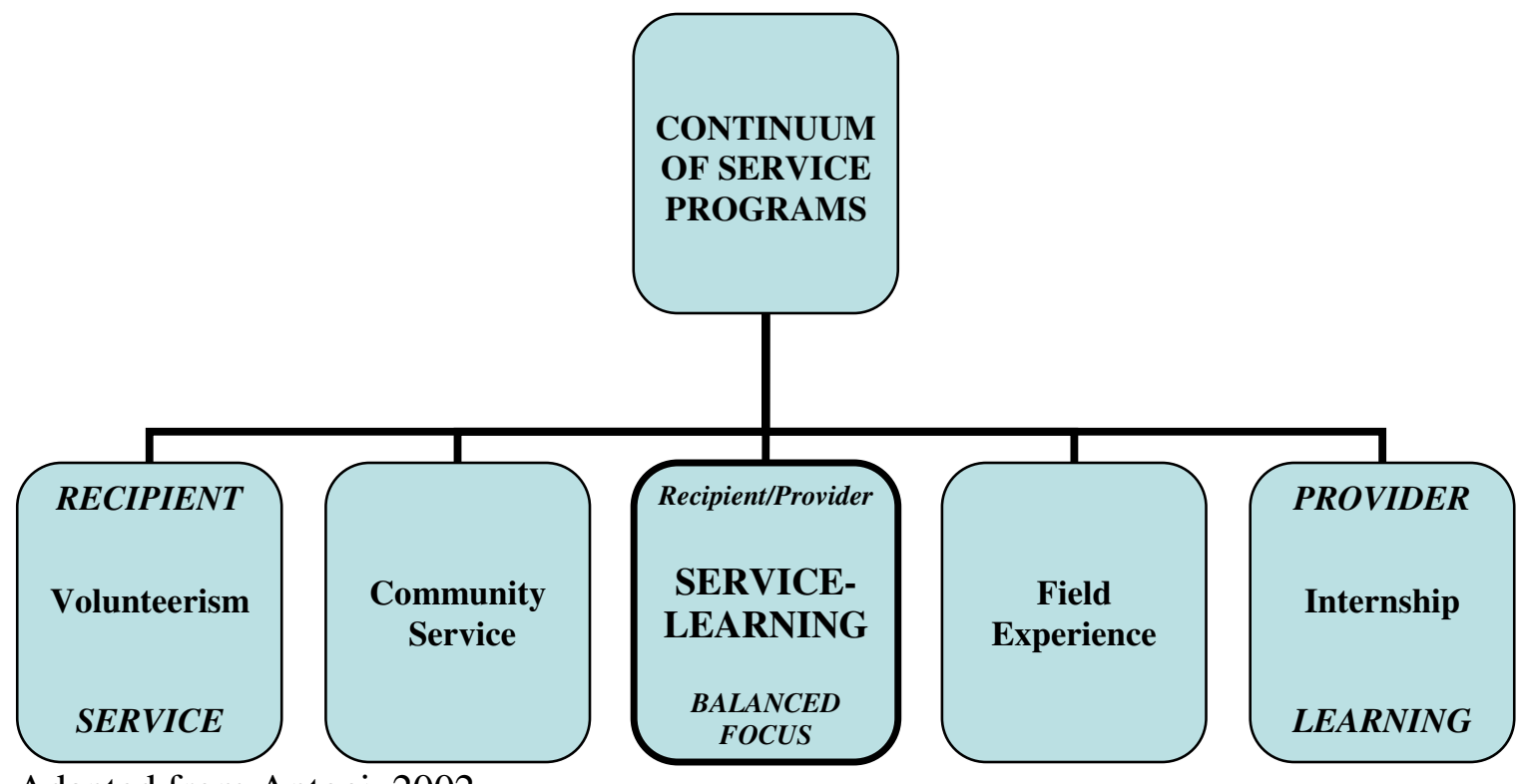

Adapted from Antoci, 2002

The mission of the Teacher Licensure Program at Liberty University is to develop competent professionals with a Christian worldview for Christian, public, and private schools. To be consistent with the mission, classroom experience in both Christian and public schools should be required for each teacher candidate who successfully completes Liberty's program. In Virginia, an added benefit is that field experience in accredited Christian schools meet the requirements of the Virginia Regulations for School Personnel, which specify "an accredited public or nonpublic school" (Virginia, 1998). 
One of the challenges in the implementation of the mission has been an inadequate number of field experience placements available in Christian school settings. Efforts have been made to increase the number of Christian school placements in the Lynchburg area through partnerships with local Christian schools. In addition, teacher candidates have been encouraged to complete field requirements and/or student teaching at accredited Christian schools in their own hometowns. Although these efforts have increased the number of available Christian school placements, the number has not been sufficient to require that every teacher candidate include field experiences in both settings. Liberty's previous field experience requirements stated that candidates were strongly encouraged to complete field experiences in a variety of K-12 classrooms, including both Christian and public school settings. The partnership has made it possible to require both settings for every teacher candidate.

A partnership between Liberty Christian Academy (LCA) and Liberty University (LU) was formed to increase the number of field experience opportunities in a Christian school setting. As a result of the partnership, the Academic Coaching program was implemented in 2006-2007. LU teacher candidates, the academic coaches, were assigned to tutor LCA students for their mutual benefit. LU teacher candidates gained practical teaching experience and exposure to Christian school education, while LCA students received personal encouragement and academic support. The recent relocation of the Academy to the LU campus facilitated the implementation of the partnership. The Academic Coaching Partnership was designed to provide equal emphasis to service and to learning for all of the participants involved, particularly the two major groups of participants in the partnership, the K-12 students at LCA and the teacher candidates at LU. 
The Academic Coaching Program was implemented in 2006-2007 as a partnership between Liberty Christian Academy and Liberty University's School of Education. Initial planning meetings for the partnership initiated in Spring, 2006, were attended by LU Administration (Chancellor, Vice-Chancellor, Executive Vice President, Provost, Vice Provost, Dean of Institute of Biblical Studies, Dean of the School of Education) and by LCA Administration (Superintendent, Lower School Principal, Upper School Principal, Vice Principal, Guidance Counselor). Additional planning meetings continued through the summer and early fall. As indicated in Figure 3, the Director of Field Experiences was designated as the primary LU contact, and the Vice Principal of Individualized Instruction was designated as the primary LCA contact. Other participants included LU education faculty and LCA classroom teachers.

Figure 3. Organizational structure of the LU-LCA partnership

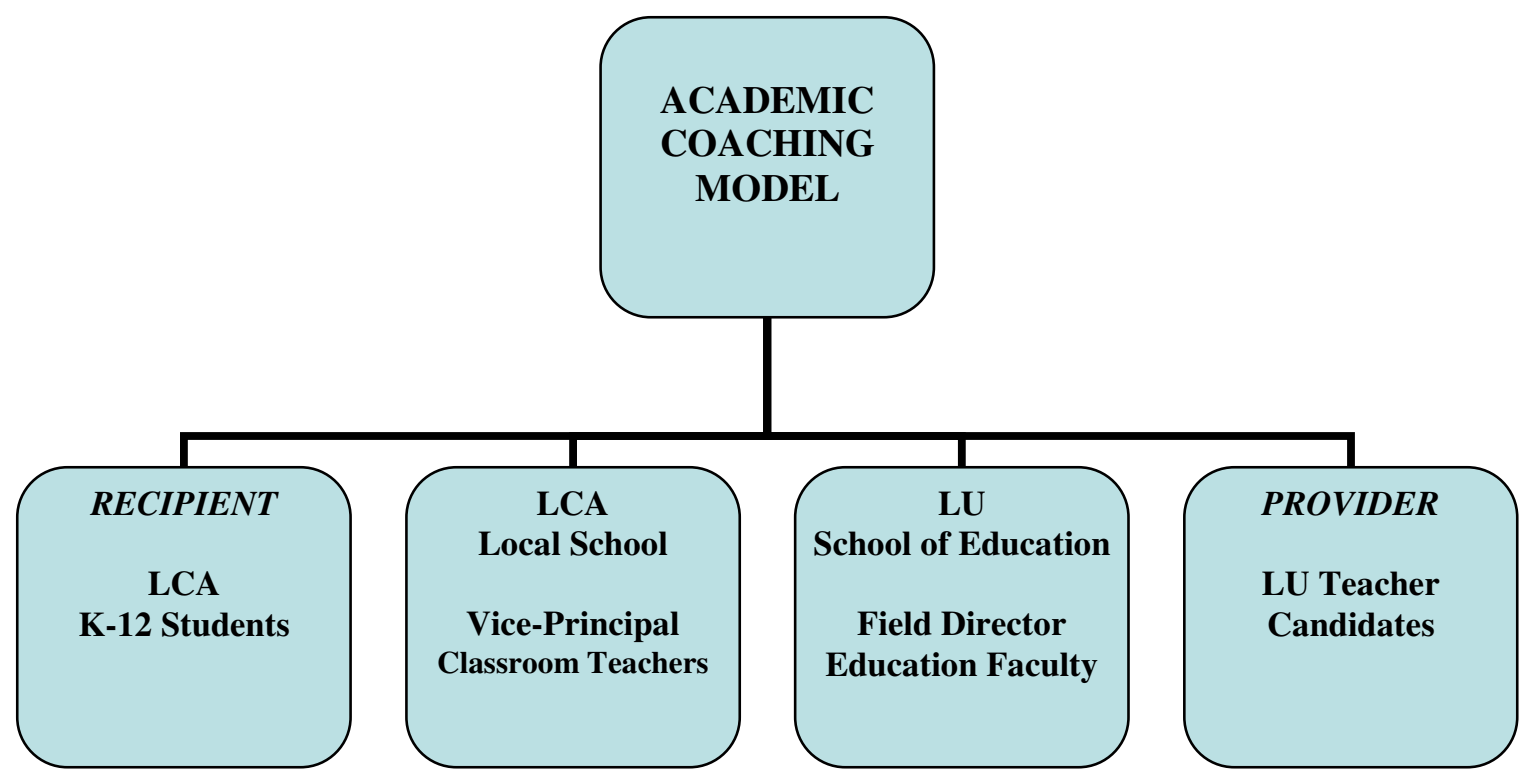

All academic coaches were LU students, primarily from teacher education classes (see Table 1). Students were also recruited from the Honors Program and from Community Service. 


\begin{tabular}{|l|l|c|}
\hline \multicolumn{2}{|l|}{ Table 1. Participants in 2006-2007 } & 64 \\
\hline Assignment level & Upper School & 86 \\
\hline & Lower School TOTAL & $\mathbf{1 5 0}$ \\
\hline Academic coaches & \multicolumn{1}{|c|}{ T } & 112 \\
\hline & Education students & 38 \\
\hline & Honors/Christian service students & 9 \\
\hline Assignment schedule & Before school & 63 \\
\hline & Lower School classrooms & 40 \\
\hline & Upper School learning labs & 38 \\
\hline & After school & $\mathbf{5 5 3}$ \\
\hline LCA students tutored & & 455 \\
\hline & Before school & 35 \\
\hline & During school & 54 \\
\hline & Learning labs & \\
\hline & After school & \\
\hline
\end{tabular}

Academic coaches in the Upper School worked with LCA students in grades 7-12 in learning labs during study hall, before school, and after school. Each learning lab was also supervised by LCA faculty. Lower School coaches were assigned to elementary classroom teachers during the school day or before or after school. Folders for coaches were provided in their assigned room so that coaches could log in and check their duties for the day.

The preliminary assessment has been made of the first year based on survey results.

Table 2 indicates the responses received from 100 Academic Coaches. One hundred percent of the coaches would participate in the program again or recommend it to others and

\begin{tabular}{|c|c|c|c|c|}
\hline $\begin{array}{l}\text { Table 2. Academic Coaches } \\
4=\text { highest to } 1=\text { lowest }\end{array}$ & 4 & 3 & 2 & 1 \\
\hline $\begin{array}{l}\text { 1. I felt welcome by the staff at Liberty Christian } \\
\text { Academy. }\end{array}$ & $89 \%$ & $11 \%$ & 0 & 0 \\
\hline $\begin{array}{l}\text { 2. My Liberty Christian Academy teacher prepared } \\
\text { me well for my assignments. }\end{array}$ & $63 \%$ & $28 \%$ & $2 \%$ & 0 \\
\hline $\begin{array}{l}\text { 3. I feel that I was provided with adequate resources } \\
\text { to perform my task. }\end{array}$ & $73 \%$ & $23 \%$ & $1 \%$ & 0 \\
\hline $\begin{array}{l}\text { 4. My coaching experience was a valuable part of } \\
\text { my education. }\end{array}$ & $77 \%$ & $20 \%$ & $1 \%$ & 0 \\
\hline $\begin{array}{l}\text { 5. I would participate in this program again/or } \\
\text { recommend it to others. }\end{array}$ & $73 \%$ & $27 \%$ & 0 & 0 \\
\hline
\end{tabular}


97\% responded positively that their coaching experience was a valuable part of their education.

The highest positive response indicated that the coaches felt welcome by the staff at LCA.

Narrative responses received from coaches are being analyzed for the final report to guide the preparation for next year.

LCA teachers were also surveyed (see Table 3). They responded positively regarding the benefit for their K-12 students, for the Academic Coaches, and for themselves as teachers.

Narrative responses were positive and suggestions for next year have been collected for summer planning sessions.

\begin{tabular}{|l|c|c|c|c|}
\hline $\begin{array}{l}\text { Table 3. LCA Teacher Survey } \begin{array}{r}\mathrm{N}=20 \\
\text { Lower school=75\% }\end{array} \\
\text { Upper school=25\% }\end{array}$ & & & & \\
\hline Please rate the benefit of the Academic Coaching: & $\begin{array}{c}\text { Major } \\
\text { impact }\end{array}$ & $\begin{array}{c}\text { Minor } \\
\text { impact }\end{array}$ & $\begin{array}{c}\text { Little } \\
\text { impact }\end{array}$ & $\begin{array}{c}\text { No } \\
\text { impact }\end{array}$ \\
\hline 1. For your students & $85 \%$ & $15 \%$ & 0 & 0 \\
\hline 2. For the college students (Academic Coaches) & $95 \%$ & 0 & 0 & 0 \\
\hline 3. For yourself, as a teacher & $80 \%$ & $20 \%$ & 0 & 0 \\
\hline
\end{tabular}

Three education classes were surveyed following their Academic Coaching experiences that were required as part of the course:

- EDSP 414 Instructional Adaptation for Special Education

- EDUC 226 Instructional Design (Elementary teacher candidates)

- EDUC 236 Instructional Design (Secondary teacher candidates)

Surveys were designed to assess competencies related to the learning objectives for each course. For EDUC 414 Instructional Adaptation for Special Education, coaches were assigned to work with the LCA special education teachers. The coaches rated the impact of their academic coaching experience on their knowledge of the competencies published by the Council for Exceptional Children (see Table 4). The LU instructor for the special education class commented that the greatest strength of the Academic Coaching Partnership at LCA was "the exposure to Christian Perspectives in Education, Vol. 1, No. 1, Fall 2007 
Christian schools for our students. Particularly, showing them a model of providing special education in a Christian school. We teach that all Christian schools should do what they can to address students with disabilities in their schools, and for our candidates to see it in action is a wonderful opportunity."

\begin{tabular}{|l|c|c|c|c|}
\hline \multicolumn{4}{|l|}{ Table 4. Special Education Coaches' Responses } & \multicolumn{4}{l|}{} \\
\hline Please rate the impact of your coaching on: & $\begin{array}{c}4 \\
\text { Major Impact }\end{array}$ & $\begin{array}{c}3 \\
\text { Minor Impact }\end{array}$ & $\begin{array}{c}2 \\
\text { No Impact }\end{array}$ & $\begin{array}{c}\text { I } \\
\text { Not Applicable }\end{array}$ \\
\hline Professionalism & $87 \%$ & $13 \%$ & 0 & 0 \\
\hline Foundations of special education & $87 \%$ & $13 \%$ & 0 & 0 \\
\hline Development and characteristics of learners & $87 \%$ & $13 \%$ & 0 & 0 \\
\hline Individual differences & $100 \%$ & 0 & 0 & 0 \\
\hline Instructional strategies & $69 \%$ & $31 \%$ & 0 & 0 \\
\hline $\begin{array}{l}\text { Learning environments and social } \\
\text { interactions }\end{array}$ & $75 \%$ & $25 \%$ & 0 & 0 \\
\hline Language & $69 \%$ & $31 \%$ & 0 & 0 \\
\hline Collaboration & $81 \%$ & $19 \%$ & 0 & 0 \\
\hline Your impact on LCA students' learning & $81 \%$ & $19 \%$ & 0 & 0 \\
\hline
\end{tabular}

The LU instructor for the elementary teacher candidates reported that "the program has been very rewarding for all of my students. All of the academic coaches have left the program excited and eager to begin the teaching profession."

Regarding the secondary teacher candidates, their LU instructor stated that "students were able to experience many of the concepts discussed in class, as reflected by some of their comments and observations:

- Students do have different learning styles. I had to come up with new strategies to get the information across.

- I saw a change in my client's low self-esteem as he saw the benefits of tutoring. Test and quiz scores started to improve.

- My client seemed lonely. I think he needed to connect with someone. Through my major, I had learned a lot about his country and was able to talk about some of its characteristics. This enabled him to open up to me and the change in his demeanor was great. 
- My client did not do well today. He was influenced by some of his friends who did not want to work. I found that I had to be stern.

- Some of the clients appear to be in need of someone to take a special interest in them. I felt good about being able to talk with them and show them I care about them. I also realize that I must guard and maintain the teacher-student relationship and make sure they understand it is not a buddy-buddy relationship.

As indicated in Table 5, academic coaches in the elementary secondary education courses rated the top four competencies that were impacted by their coaching experiences as communication, human relations, diversity, and impact on students' learning.

\begin{tabular}{|l|c|c|c|c|}
\hline \multicolumn{3}{|l}{ Table 5: Elementary/Secondary Coaches' Responses } & \multicolumn{2}{c|}{$\mathrm{N}=24$} \\
\hline Please rate the impact of your coaching on: & $\begin{array}{c}4 \\
\text { Major Impact }\end{array}$ & $\begin{array}{c}3 \\
\text { Minor Impact }\end{array}$ & $\begin{array}{c}\mathbf{2} \\
\text { No Impact }\end{array}$ & $\begin{array}{c}1 \\
\text { Not Applicable }\end{array}$ \\
\hline 1. General and professional knowledge & $46 \%$ & $42 \%$ & $8 \%$ & $4 \%$ \\
\hline 2. Communication & $79 \%$ & $8 \%$ & $8 \%$ & $4 \%$ \\
\hline 3. Planning & $21 \%$ & $50 \%$ & $17 \%$ & $12 \%$ \\
\hline 4. Curriculum & $42 \%$ & $42 \%$ & $4 \%$ & $12 \%$ \\
\hline 5. Human relations & $87 \%$ & $4 \%$ & $8 \%$ & 0 \\
\hline 6. Diversity & $71 \%$ & $8 \%$ & $17 \%$ & $4 \%$ \\
\hline 7. Classroom management & $50 \%$ & $25 \%$ & $12 \%$ & $12 \%$ \\
\hline 8. Assessment & $25 \%$ & $42 \%$ & $29 \%$ & $4 \%$ \\
\hline 9. Technology and resources & $8 \%$ & $25 \%$ & $33 \%$ & $33 \%$ \\
\hline 10. Professionalism & $54 \%$ & $21 \%$ & $17 \%$ & $8 \%$ \\
\hline 11. Content knowledge of your subject area & $46 \%$ & $17 \%$ & $17 \%$ & $21 \%$ \\
\hline 12. Your impact on K-12 students' learning & $75 \%$ & $17 \%$ & $8 \%$ & 0 \\
\hline
\end{tabular}

Academic coaches in the elementary/secondary education courses were also surveyed regarding their experiences in Christian schools (see Table 6). They were sophomore-level college students. Academic coaching was their second required field experience in the Teacher Licensure Program. When asked how many years they had attended Christian schools in grades $\mathrm{K}-12,25 \%$ indicated that they had not attended Christian schools, $21 \%$ had attended all grades $\mathrm{K}-12$, and $54 \%$ had attended from 1 to 7 years. 


\begin{tabular}{|l|c|c|}
\hline Table 6. Christian school experience N=25 & Yes & No \\
\hline Did you attend a Christian school in grades K-12? & $75 \%$ & $25 \%$ \\
\hline $\begin{array}{l}\text { Did you have any field experience in a Christian School prior to Academic } \\
\text { Coaching at LCA? }\end{array}$ & $38 \%$ & $62 \%$ \\
\hline $\begin{array}{l}\text { Before your Academic Coaching at LCA, would you have considered working in } \\
\text { a Christian school after graduation? }\end{array}$ & $62 \%$ & $38 \%$ \\
\hline $\begin{array}{l}\text { After your Academic Coaching at LCA, would you now consider working in a } \\
\text { Christian school after graduation? }\end{array}$ & $92 \%$ & $8 \%$ \\
\hline
\end{tabular}

It is encouraging to note that following the Academic Coaching experience, there was a $30 \%$ increase in the number of academic coaches who would consider teaching in a Christian school after graduation. Of particular interest is the fact that all students who had not previously considered working in a Christian school also responded that they had no previous experience in a Christian school, including attendance in K-12 or field experience. The increase following the field experience in a Christian school supports the importance of a required Christian school experience for every teacher candidate.

In conclusion, the preliminary assessment of the Academic Coaching Partnership between Liberty University and Liberty Christian Academy indicated a successful first year, based on survey results from all stakeholders. The LU-LCA partnership exemplified the following research-based principles for effective service learning: 1) grounding in a spiritual mission, 2) character virtues of mentors, 3) strength-based school setting, 4) effective guided reflection, 5) equal emphasis on service and learning, 6) solving a problem in the community, and 7) fulfilling an academic requirement.

Service learning partnerships are mutually beneficial for pre-service teachers and K-12 students. In light of their spiritual mission, Christian colleges should be especially encouraged to develop service-learning partnerships to increase available field experiences in K-12 Christian schools. Service-learning is the outward manifestation of our mission as Christians. As Jesus 
commanded, "And whosoever will be chief among you, let him be your servant: Even as the Son of man came not to be ministered unto, but to minister" (Matthew 20:27-28 KJV). 


\section{References}

Anderson, J. (1998). Service-learning and teacher education. (ERIC Document Reproduction Service No. ED421481)

Antoci, P. M., \& Speck, S. K. (2002). Service-learning and community partnerships: Curricula of mutuality. In R. Devine (Ed.), From cloister to commons: Concepts and models for service-learning in religious studies (pp. 69-75). Washington, DC: American Association for Higher Education.

Bringle, R.\& Hatcher, J. (1997). Reflection. College Teaching, 45(4), p. 153. Retrieved March 1, 2007 from Academic Search Premier database.

Furco, A. (1996). Service-learning: A balanced approach to experiential education. Expanding boundaries: Service and learning. Washington, DC: Corporation for National Service.

Harvaky, I., \& Romer, D. (1999). Service learning as an integrated strategy. Liberal Education, 85(3), 14. Retrieved March 1, 2007 from the Academic Search Premier database.

Hasseler, S. S. (2002). Powerful paradigms and community contexts: Service-learning in teacher-education programs. In G. G. Heffner \& C.D. Beversluis (Eds.), Commitment and connection: Service-learning and Christian higher education (pp. 141-151). New York: University Press of America.

Hickcox, L. K. (2002). Personalizing teaching through experiential learning. College Teaching, 45(4), pp. 123-128.

Hodge, G., Lewis, T, Kramer, K. \& Hughes, R. (2001). Collaboration for excellence: Engaged scholarship at Collin County Community College. Community College Journal of Research and Practice, 25, pp. 675-690. 
Hubbert, K. (2002). Service learning and learning communities. (ERIC Document Reproduction Service No. ED466259O)

Lizzio, A., \& Wilson, K. (2004). Action learning in higher education: An investigation of its potential to develop professional capability. Studies in Higher Education, 29(4), 469-488.

McGowan, T. G. (2002). Toward an assessment-based approach to service-learning course design. In R. Devine (Ed.), From cloister to commons: Concepts and models for servicelearning in religious studies (pp. 83-91). Washington, DC: American Association for Higher Education.

Schaffer, R. H. (2004). Service-learning in Christian higher education: Bringing our mission to life. Christian Higher Education, 3, pp. 127-145.

Sigmon, R. (1994). Serving to learn, learning to serve. Linking Service with Learning. Washington, DC: Council of Independent Colleges.

Valo, M. (2000). Experiencing work as a communications professional: Students' reflections on their off-campus work practice. Higher Education, 39, 151-179.

Virginia Licensure Regulations for School Personnel (1998). Richmond, VA: State Board of Education.

Wilson, P. F., \& Johnson, W. B. (2001). Core virtues for the practice of mentoring. Journal of Psychology and Theology, 29(2), 121-130. 